\title{
CARDIOPROTECTIVE POTENTIAL OF QUERCETIN AGAINST DIESEL OR PETROL EXHAUST NANOPARTICLE INDUCED TOXICITY: A PROSPECTIVE IN VITRO PHARMACOLOGICAL STUDY IN H9C2 CELLS
}

\author{
MOHAN DURGA ${ }^{1 *}$, THIYAGARAJAN DEVASENA ${ }^{2}$ \\ ${ }^{1}$ Department of Biochemistry and Bioinformatics, Dr MGR Janaki College of Arts and Science for Women, Chennai, Tamil Nadu, India. \\ ${ }^{2}$ Centre for Nanoscience and Technology, Anna University, Chennai, Tamil Nadu, India. Email: durgam2k7@gmail.com
}

Received: 22 January 2021, Revised and Accepted: 02 March 2021

\begin{abstract}
Objective: Phytochemicals are known to elicit potential antioxidant activity. This study examined the cardioprotective effects of quercetin against oxidative damage to rat cardiomyocyte cells (H9c2) after treatment with Diesel Exhaust Nanoparticles (DEPs) or Petrol Exhaust Nanoparticles (PEPs).
\end{abstract}

Methods: Cardiomyocyte cells were exposed to DEPs or PEPs alone and in a combination with quercetin for $24 \mathrm{~h}$.

Results: Results showed that quercetin had no lethal effect on H9c2 cells up to a concentration of $1.0 \mu \mathrm{g} / \mathrm{ml}$. Exposure to DEPs (4.0 $\mu \mathrm{g} / \mathrm{ml}$ ) or PEPs $(10.0 \mu \mathrm{g} / \mathrm{ml})$ induced cytotoxicity, oxidative stress, and inflammation $(\mathrm{p}<0.05)$. It also provoked lipid peroxidation by an increase in MDA and a decrease in SOD activity and glutathione activity $(\mathrm{p}<0.05)$. Simultaneous addition of quercetin restored these parameters to near normal.

Conclusion: These results thus specify that quercetin plays a protective role in cardiac cells exposed to DEPs and PEPs.

Keywords: Diesel exhaust nanoparticles, Petrol exhaust nanoparticles, H9c2, Antioxidants, Quercetin, Inflammation.

(C) 2021 The Authors. Published by Innovare Academic Sciences Pvt Ltd. This is an open access article under the CC BY license (http://creativecommons.org/ licenses/by/4.0/) DOI: http://dx.doi.org/10.22159/ajpcr.2021v14i4.40858. Journal homepage: https://innovareacademics.in/journals/index.php/ajpcr

\section{INTRODUCTION}

Flavonoids are a group of natural, polyphenolic compounds found widely in fruits, flowers, vegetables, stem, wine, and tea. Nearly 400 different flavonoids have been discovered till date. Quercetin $(3,5,7,3,4$ - pentoxy flavones) is one of the best illustrated flavonoids with potential antioxidant properties [1]. Quercetin was found in its glycosylated form in apples, onions, broccoli, and French beans [2]. Studies revealed that quercetin intake showed decreased frequency of neoplastic and cardiovascular diseases [3-5]. Studies by Tieppo et al., 2007, reported that quercetin increased the genomic stability and hence enhanced the antioxidant defense system in rat models [6]. Studies also showed that quercetin inhibited the expression of nitric oxide (NO) synthase, cyclooxygenase, lipid peroxidation (LPO), and xanthine oxidase [7]. Farombi and Onyema, 2006, indicated that dietary antioxidants such as quercetin, Vitamin E, and Vitamin C played a protective role against oxidative stress induced by monosodium glutamate in the brain, liver, and kidney of rats [8]. Studies showed that quercetin prevented different disorders caused by environmental contaminants [9].

Environmental contaminants such as diesel exhaust nanoparticles (DEPs) and petrol exhaust nanoparticles (PEPs), pose a great threat to human health because of their small size and cause dangerous effects such as asthma, bronchitis, various allergies, and lung cancer [10]. As a component of particulate matter (PM), DEPs were seen to exhibit lethal effects on cardiac cells both in vivo and in vitro. In vitro studies showed that different cell types took up DEPs and induced inflammation and oxidative stress in various cell types [11]. DEPs evoked cardiac failure in rats [12]. Other studies showed that DEPs induced reactive oxygen species (ROS) formation and hence oxidative stress and inflammation in the lung and respiratory tract of rats [13]. Studies also showed that DEPs induced toxicity by the production of hydroxyl radicals [14].

Reproductive toxicity evoked by DEPs in rats was treated by quercetin [15]. Other studies showed that quercetin exhibited ameliorating effects on reproductive toxicity induced by 3-methyl-4-nitrophenol (PNMC) (a vital component of DEPs) in chicken embryos [16]. Available data's on PEP toxicity are insufficient and hence need to be studied in detail.

To the finest of our acquaintance, there are no data's in the available literature reporting the protective effect of quercetin on DEP/PEPinduced cardiotoxicity. The current study was thus, undertaken to investigate the anti-toxic and antioxidant effects of quercetin in DEP/ PEP-induced cardiotoxicity in vitro.

\section{METHODS}

Chemicals

Quercetin (98.5\%) was purchased from Sigma-Aldrich Pvt. Ltd., Bengaluru, India. All other analytical grade chemicals were purchased from HiMedia Laboratories, Mumbai, India.

\section{Collection and characterization of nanoparticles}

The collection and characterization of nanoparticles were done according to our previous study [17].

\section{Cell culture and MTT assay}

H9c2 cells (Rat cardiomyocyte cell line) were used for the determination of cytotoxic end-points. The cell lines were purchased from National Centre for Cell Science, Pune. Cytotoxicity determination $\left(\mathrm{IC}_{50}\right)$ of DEPs and PEPs was performed by MTT assay according to our previous study [17]. The different concentrations of Quercetin (Q) were added to the cells in $100 \mu \mathrm{L}$ of medium and incubated for $24 \mathrm{~h}$. After $24 \mathrm{~h}$ of incubation, $10 \mu \mathrm{L}$ MTT was added to each well and incubated further for $4 \mathrm{~h} .100 \mathrm{ml}$ of DMSO solution was added to each well for the formazan crystal solubilization. The wells were then quantified by measuring absorbance of the solution at $570 \mathrm{~nm}$ using a microplate reader (BIO$\mathrm{RAD}, \mathrm{USA})$. The $\mathrm{IC}_{50}$ value was calculated from the absorbance.

Experimental design for cardioprotective activity

The cells were incubated in medium containing DEP or PEP with or without prior treatment with quercetin. $1 / 25^{\text {th }}$ IC $_{50}$ value of DEP 
$(4.0 \mu \mathrm{g} / \mathrm{ml})$ and PEP $(10.0 \mu \mathrm{g} / \mathrm{ml})$ was taken. $1 / 10^{\text {th }}$ and $1 / 25^{\text {th }}$ IC ${ }_{50}$ of $\mathrm{Q}$ $(2.5 \mu \mathrm{g} / \mathrm{ml}$ and $1.0 \mu \mathrm{g} / \mathrm{ml})(\mathrm{Q} 1$ and Q 2) were chosen for the study. The maximum concentrations of DEPs and PEPs were taken based on the relevant concentration of PM2.5 in urban air [18]. The control received vehicle only. After $24 \mathrm{~h}$ exposure, the medium and cultured cells were used to determine NO, Total Protein (TP), Lactate Dehydrogenase (LDH), Superoxide Dismutase (SOD), Glutathione (GSH), Malondialdehyde (MDA), intracellular Hydrogen peroxide $\left(\mathrm{H}_{2} \mathrm{O}_{2}\right.$ ), and cytokines (TNF $\alpha$, IL-6, and IL-8).

Measurement of NO, TP, and LDH in cell culture supernatant fluids H9c2 cells were seeded into 6-well plates at a density of 5000 cells/ well in $100 \mu \mathrm{L}$ of medium. Cells were allowed to proliferate attach and cover around $80 \%$ of the plate surface area before exposure to different treatment groups for $24 \mathrm{~h}$. After $24 \mathrm{~h}$ of exposure, the culture supernatants were collected to determine the levels of NO (Biovision Inc), TP (Bio-rad, USA), and LDH (Sigma-Aldrich, India). The TP levels were measured using a Coomassie Brilliant Blue protein assay kit. The LDH activity was determined spectrophotometrically in the presence of lactate by observing the reduction of NAD+ at $340 \mathrm{~nm}$, according to the manufacturer's protocol. The NO levels were determined using a nitric acid reductase kit according to the manufacturer's protocol.

\section{Measurement of intracellular SOD, GSH, and MDA}

H9c2 cells were seeded into 6-well plates at a density of 5000 cells/ well in $100 \mu \mathrm{L}$ of medium and allowed to proliferate, attach, and cover around $80 \%$ of the plate surface area before the treatment for $24 \mathrm{~h}$. After $24 \mathrm{~h}$ treatment, the cells were washed with ice-cold phosphate buffered saline (PBS), followed by trypsinization and immediate disruption by continuous frozen-thaw process ( 3 times). The cell lysates were collected, centrifuged, and stored at $-20^{\circ} \mathrm{C}$ for the determination of intracellular SOD, GSH, and MDA (Sigma-Aldrich, India) using commercial kits following the manufacturer's instructions.

\section{Measurement of intracellular $\mathrm{H}_{2} \mathrm{O}_{2}$ formation}

H9c2 cells were seeded into 6-well plates at a density of 5000 cells/ well in $100 \mu \mathrm{L}$ of culture medium and allowed to proliferate attach and cover around $80 \%$ of the plate surface area before exposure to different treatment groups. The intracellular $\mathrm{H}_{2} \mathrm{O}_{2}$ was determined by the chemiluminescence (CL) method using horseradish peroxidase (HRP). After $1 \mathrm{~h}$ treatment, the cells were collected, rinsed with ice-cold PBS and followed by trypsinization. For the radical measurement, the cell lysates were centrifuged, washed, and suspended in two different Eppendorf's containing $400 \mu \mathrm{L}$ PBS. To this, $8 \mu \mathrm{L}$ of HRP and $4 \mu \mathrm{L}$ luminol were added. CL was measured at $25^{\circ} \mathrm{C}$ for each second from the $0^{\text {th }}$ to $9^{\text {th }} \mathrm{S}$ with a Luminometer apparatus (Zylux, U.S.).

\section{Measurement of cytokine secretion in $\mathrm{H} 9 \mathrm{c} 2$ cell lines}

H9c2 cells were seeded into 6-well plates at a density of 5000 cells/ well in $100 \mu \mathrm{L}$ of culture medium and allowed to proliferate attach and cover around $80 \%$ of the plate surface area before exposure to different treatment groups. DEPs and PEPs were suspended in sterile normal saline $(\mathrm{NaCl} 0.9 \%)$ containing Tween $80(0.01 \%)$. The setup was incubated with DEPs and PEPs up to $24 \mathrm{~h}$ at $37^{\circ} \mathrm{C}$ in a humidified atmosphere containing $5 \% \mathrm{CO}_{2}$. After 12 and $24 \mathrm{~h}$, the quantitative measurement of pro-inflammatory cytokines (IL-8, TNF- $\alpha$, and IL-6) was performed in the supernatants. Supernatants were collected by centrifugation of culture medium at $2500 \mathrm{rpm}$ for $20 \mathrm{~min}$ at $18^{\circ} \mathrm{C}$ and assayed for and TNF- $\alpha$, IL- 6 , and IL-8 using commercial ELISA assay kits (ebiosciences, USA), according to the manufacturer's recommendations. The samples and standards were all run in triplicates and the data's were analyzed.

\section{Statistical analysis}

All experiments were performed in triplicates. The results were expressed as mean \pm SD. Data were analyzed by standard statistical analysis one-way ANOVA with Duncan's test for multiple comparisons to determine significance between different groups. The results were considered statistically significant if "p" value was 0.05 or less.

\section{RESULTS}

From the MTT assay, the $\mathrm{IC}_{50}$ values for DEP, PEP, and Q treated H9c2 cells were found to be $100 \mu \mathrm{g} / \mathrm{ml}, 250 \mu \mathrm{g} / \mathrm{ml}$, and $25.80 \mu \mathrm{g} / \mathrm{ml}$, respectively (Fig. 1). The levels of LDH, TP, and NO increased significantly in DEP/ PEP treated $\mathrm{H} 9 \mathrm{c} 2$ cells while the $D E P+Q$ or $P E P+Q$ treated groups showed a significant decrease $(\mathrm{p}<0.05)$ in all the above cytotoxicity parameters (Fig. 2a-c).

The activities of cell antioxidants SOD and GSH decreased significantly $(p<0.05)$ in DEP/PEP treated groups, while the $D E P+Q$ and $P E P+Q$ groups showed a significant increase in these cells antioxidants when compared to the DEP or PEP treated groups alone ( $p<0.05$; Fig. $3 a$ and $b)$. The levels of MDA and $\mathrm{H}_{2} \mathrm{O}_{2}$ in DEP/PEP treated $\mathrm{H} 9 \mathrm{c} 2$ cells showed significant increase when compared to the control $(\mathrm{p}<0.05)$ and the levels were near normal in DEP $+Q$ and $P E P+Q$ treated H9c2 cells ( $p<0.05$; Fig. $3 c$ and $d)$.

DEP or PEP treated H9c2 cells showed a significant increase $(\mathrm{p}<0.05)$ in the levels of pro-inflammatory cytokines (TNF- $\alpha$, IL-6, and IL-8) when compared with the normal control cells. The $\mathrm{DEP}+\mathrm{Q}$ or $\mathrm{PEP}+\mathrm{Q}$ groups showed a significant decrease in these biomarkers when compared to the DEP or PEP treated cells (Fig. 4a-c).

\section{DISCUSSION}

The overall outcome of the present study proposes that exposure to DEPs $(4.0 \mu \mathrm{g} / \mathrm{ml})$ or PEPs $(10.0 \mu \mathrm{g} / \mathrm{ml})$ induces significant cytotoxicity, oxidative stress, and inflammation $(\mathrm{p}<0.05)$ in $\mathrm{H} 9 \mathrm{c} 2$ cells. This is apparent from (a) increase in levels of LDH, TP, and NO, indicators of cytotoxicity, (b) decrease in the activity of detoxifying enzymes, SOD and GSH, (c) increase in the levels of MDA and $\mathrm{H}_{2} \mathrm{O}_{2}$, and (d) increase in the levels of pro-inflammatory cytokines IL-6, IL-8, and TNF- $\alpha$.

Environmental pollution is identified as a universal problem. Both DEPs and PEPs are major contributors of environmental air pollution. They evoke oxidative stress and thus influence the antioxidant mechanism of the cell by either the inhibition or enhancement of a range of antioxidant enzymatic or non-enzymatic functions. In the current study, the cardio-protective effect of quercetin (Q) was examined in DEP/PEP induced toxicity.

Cells exhibit structural alterations and disturbances in cell function and antioxidant defense organization following exposure to environmental pollutants and toxic chemicals. Increase in levels of cytotoxicity marker enzymes (LDH, TP, and NO) in cell culture supernatants was found in the present study. They are key indicators of cytotoxicity and cell membrane damage. Cell death or cellular toxicity involves complex mechanisms that entail detailed evaluation.

LDH is distributed extensively in the cytoplasm of cells, yeasts, mammalian tissues, and bacteria. LDH is released from the cytosol by cell lysis. LDH release in regarded as a late episode in apoptosis and

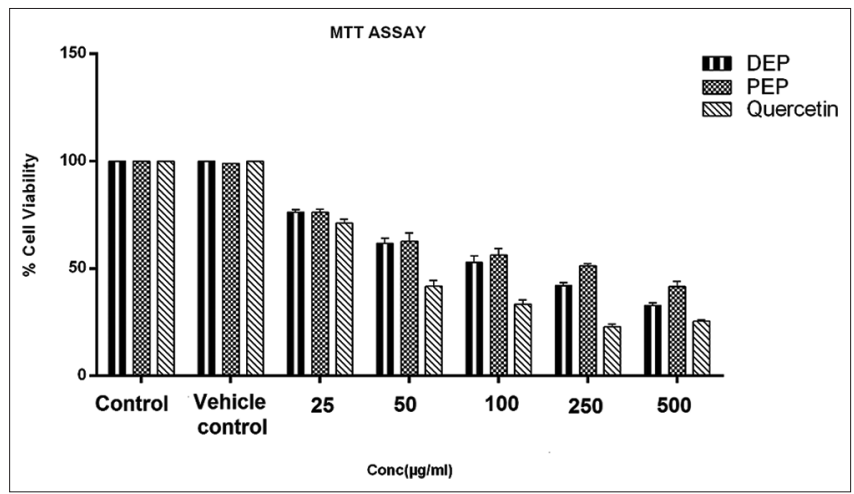

Fig. 1: Cell viability of DEPs, PEPs, and Q exposed to H9c2 cells for $24 \mathrm{~h}$ was determined by MTT assay. Data are expressed as percentage of the control at the concentration of $25,50,100,250$, and $500 \mu \mathrm{g} / \mathrm{ml}$, respectively 


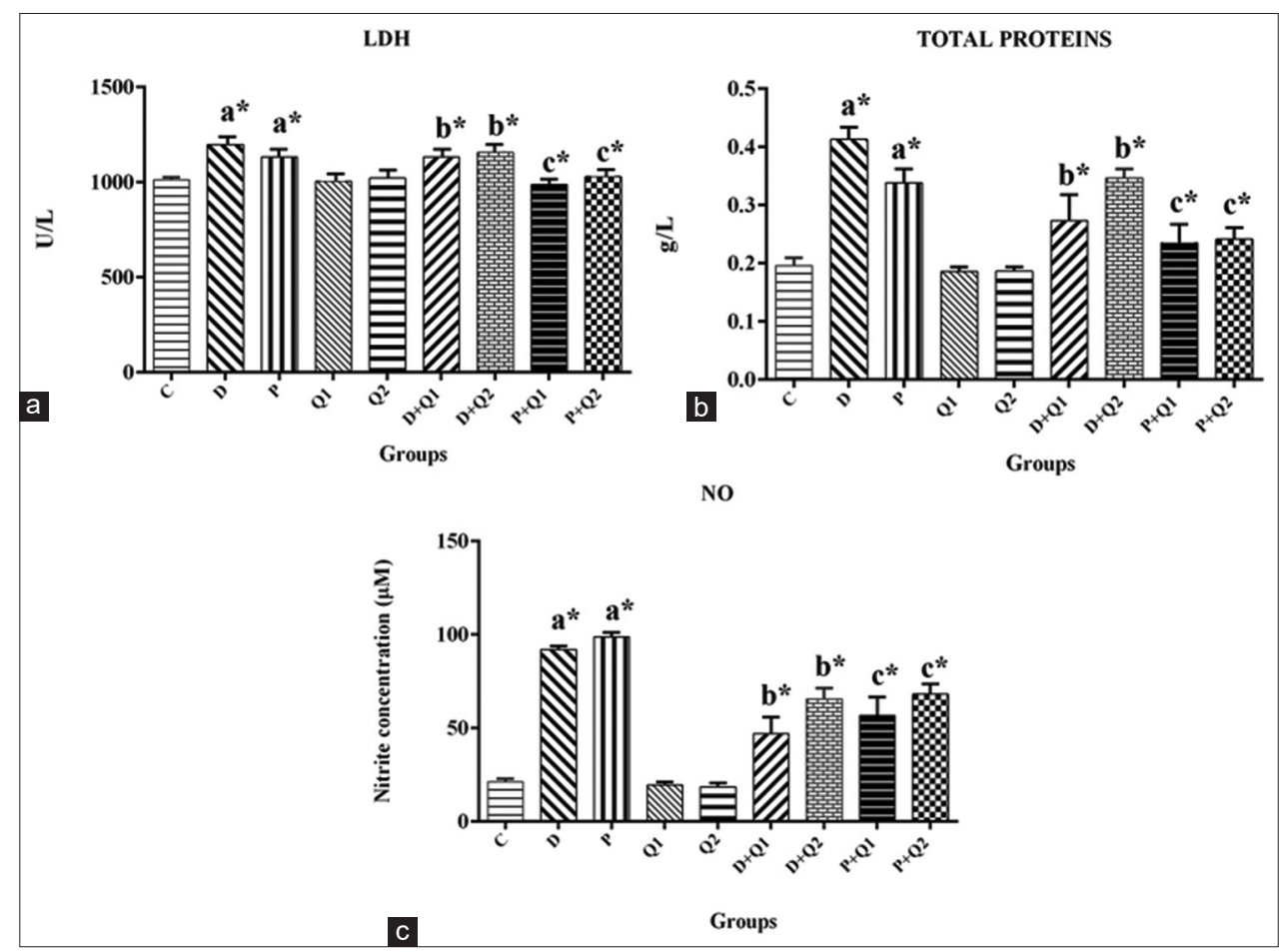

Fig. 2: (a-c) Levels of LDH, TP, and NO in H9c2 cells treated with DEP $(4.0 \mu \mathrm{g} / \mathrm{ml})$, PEP (10.0 $\mu \mathrm{g} / \mathrm{ml}), \mathrm{Q} 1(2.50 \mu \mathrm{g} / \mathrm{ml})$, and Q2 (1.0 $\mu \mathrm{g} / \mathrm{ml})$ for $24 \mathrm{~h}$. Values are represented as mean \pm SD of three repeated experiments; (a) as compared with Group I (control); (b) as compared with Group II (DEP treated); and (c) as compared with Group III (PEP treated; *p<0.05)

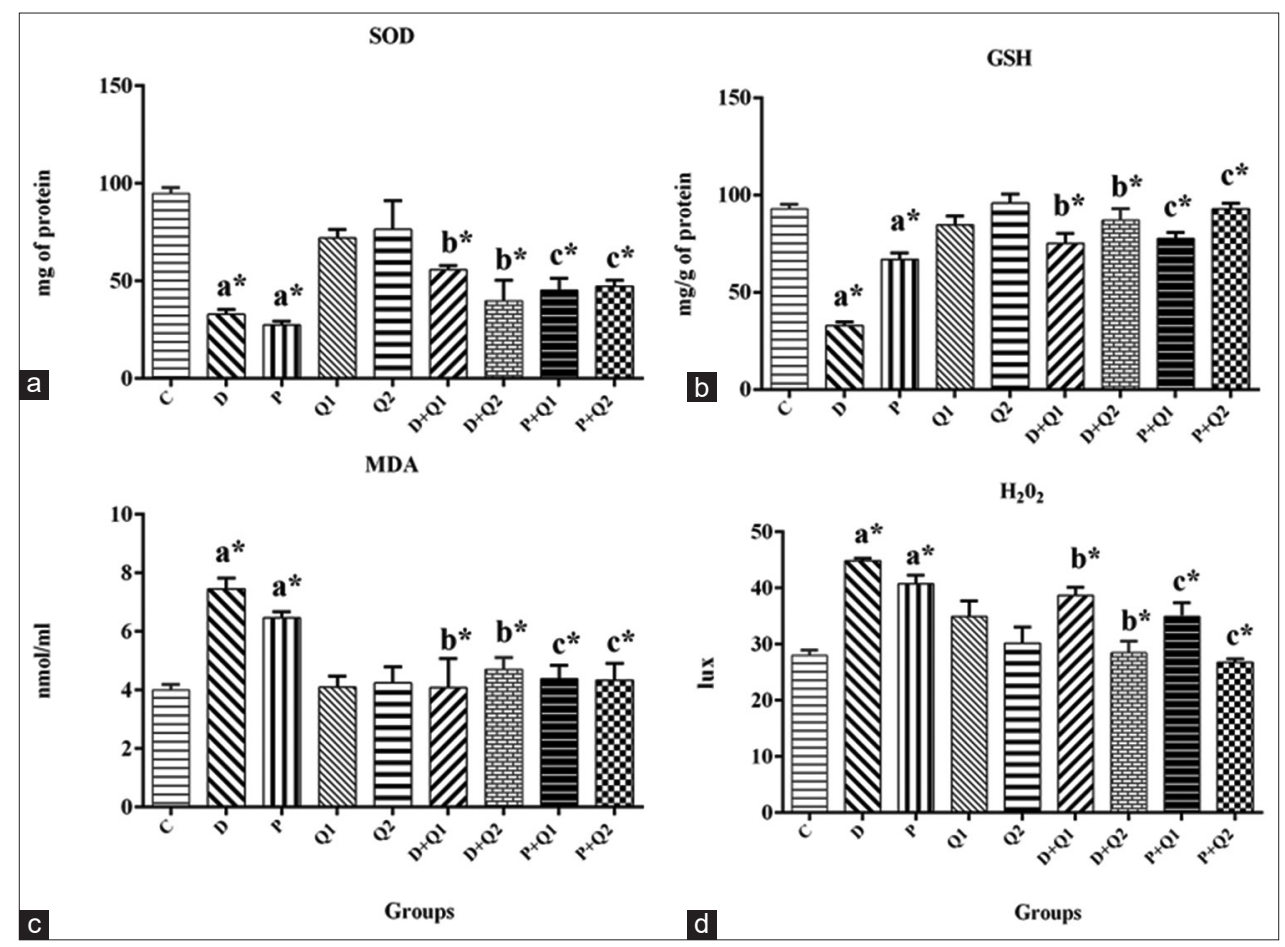

Fig. 3: (a-d) Levels of SOD, GSH, MDA, and H2O2 in H9c2 cells treated with DEP (4.0 $\mu \mathrm{g} / \mathrm{ml}), \mathrm{PEP}(10.0 \mu \mathrm{g} / \mathrm{ml}), \mathrm{Q1}(2.50 \mu \mathrm{g} / \mathrm{ml})$, and Q2 $(1.0 \mu \mathrm{g} / \mathrm{ml})$ for $24 \mathrm{~h}$. Values are represented as mean \pm SD of three repeated experiments; (a) as compared with Group I (control); (b) as compared with Group II (DEP treated); and (c and d) as compared with Group III (PEP treated; * $\mathbf{p}<0.05$ )

as an early event in necrosis. An exact temporal evaluation of toxic responses is needed as apoptosis may change into necrosis and cell viability is lost without any noticeable cell morphological alterations or response to assays determining the late events hence resulting in toxicity being unnoticed [19]. Therefore, by assessing the LDH activity alterations in cellular factors such as cell damage and impermeability can be determined. In the present study, membrane damage was evaluated by release of enzyme $\mathrm{LDH}$, since cell membrane could be a possible site for the interaction of exhaust nanoparticles.

Protein plays an important role in the metabolic activities of the cell. It is regarded as the main nutrient used by cells to develop tissues. In the 


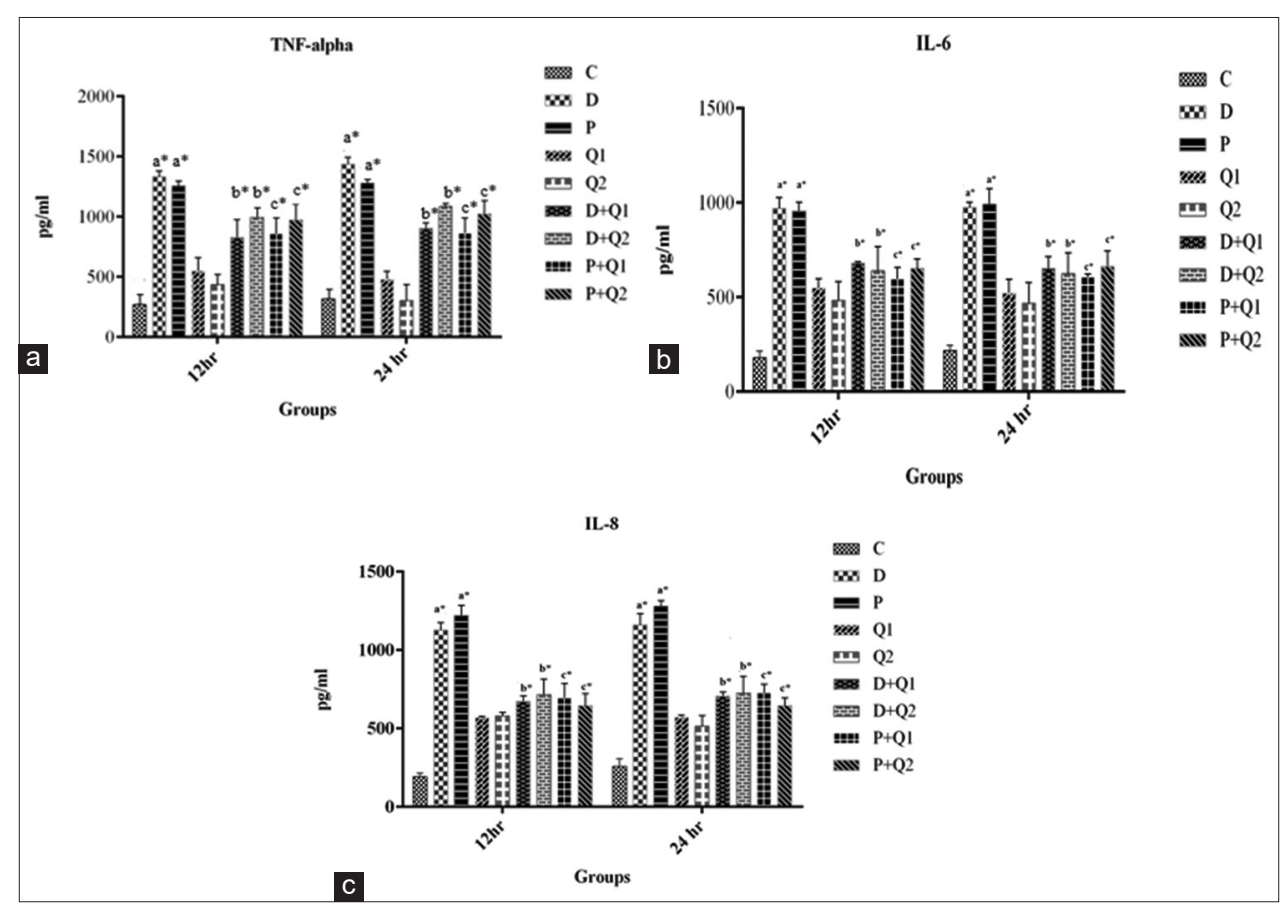

Fig. 4: (a-c) Levels of TNF- $\alpha$, IL-6, and IL-8 in H9c2 cells treated with DEP $(4.0 \mu \mathrm{g} / \mathrm{ml})$, PEP $(10.0 \mu \mathrm{g} / \mathrm{ml}), \mathrm{Q1}(2.50 \mu \mathrm{g} / \mathrm{ml})$, and Q2 (1.0 $\mu \mathrm{g} /$ $\mathrm{ml}$ ) for $24 \mathrm{~h}$. Values are represented as mean $\pm \mathrm{SD}$ of three repeated experiments; (a) as compared with Group I (control); (b) as compared with Group II (DEP treated); and (c) as compared with Group III (PEP treated; $\left.{ }^{*} \mathbf{p}<0.05\right)$

current study, it was seen that an increase in the TP content depends on the concentration of toxins in the cell culture medium. The increased protein content possibly suggests stress produced by the exhaust nanoparticles [20].

NO is a potential signaling molecule that acts as a pro-inflammatory mediator under abnormal conditions such as oxidative stress [21]. NO is produced by various cells involved in inflammation and immunity. High levels of cytokines induce the production of NO in cells. At elevated concentrations of NO, generated by NO synthase - 2 (NOS-2), "NO" is oxidized to Reactive Nitrogen Oxide Species (RNOS), that induces most of the inflammatory responses. NO can be oxidized and complexed with lipids and proteins contributing to local tissue or cell injury [22]. Many key enzymes in the mitochondria are repressed by RNOS, leading to the exhaustion of cellular energy and ATP. Such interactions of NO, explain its vital action in the inflammatory and immune cells [23]. Thus, results of the present study revealed considerable cytotoxicity and cell membrane damage contributed by the exhaust nanoparticles. The increase in LDH, TP, and NO was significantly decreased in combination with quercetin as compared with the DEP or PEP treatment alone ( $<<0.05$; Fig. 2a-c).

The decrease in SOD and GSH activities in H9c2 cells is due to the inactivation of the antioxidant enzymes as the superoxide anions are shown to decrease the enzyme activity [24]. The decrease in GSH along with the depletion of SOD may affect the cells ability to scavenge hydroxyl radicals and superoxide anions. The decrease in GSH content by DEP/PEP intoxication can also be due to the DEP/PEP-SH binding, depletion of GSH, or due to GSH reductase levels [25]. The antioxidants defend the cell membrane from oxidative stress and thus prevent oxidative damage [26]. Oxidative stress is explained as the imbalance situation involving decreased antioxidants or increased oxidants [27].

The human cells are constantly damaged by ROS, which arise by exposure to toxins in environment. Under normal conditions the body protects cells from oxidative stress by various non-enzymatic and enzymatic antioxidants [28]. Among antioxidants catalase, decomposes $\mathrm{H}_{2} \mathrm{O}_{2}$ to non-toxic products whereas, the decomposition of superoxide to $\mathrm{H}_{2} \mathrm{O}_{2}$ and oxygen is the major function of SOD. Thus, the depletion in activities of SOD and GSH in cells signifies its decrease in the cells as a result of DEP/PEP intoxication.

Oxidative stress due to increase in mitochondrial $\beta$-oxidation, microsomal $\omega$-oxidation, and peroxisomal $\beta$-oxidation leads to LPO which, in turn, causes the release of MDA and hence cellular damage [29,30]. Increased MDA levels in the current study indicated damage to cell membrane by LPO. LPO was seen as the main molecular mechanism involved in DEP/PEP-induced toxicity. This status became evident by significant rise in MDA levels when H9c2 cells were incubated with different concentrations of DEP and PEP for $24 \mathrm{~h}$. The increased exposure of cells to free radicals/ROS resulted in the oxidative degradation of lipids. Cell damage arises when the free radicals take electrons from membrane lipids. At present, LPO is regarded as the major molecular mechanism engaged in oxidative cellular damage and toxicity processes leading to cell death. The cell membrane primarily composed of polyunsaturated fatty acids act as the primary target for attack by ROS, hence directing to oxidative cell damage. Breakdown of phospholipids occurs mostly in the phospholipid membrane, mitochondria, peroxisomes, and microsome. The products of LPO were seen involved in nephrotoxicity, hepatotoxicity, and neurotoxicity [27]. Oxidative stress caused by $\mathrm{H}_{2} \mathrm{O}_{2}$ (free radicals) is an important feature of several acute and chronic infections and is currently considered as one of the main reasons leading to the adverse health impacts of airborne PM.

Earlier studies on DEP showed that inflammatory markers influence systemic cells by a TNF- $\alpha$ dependent mechanism with an increase in chemokines and cytokines [31]. Recent work on DEPs showed an increase in IL- 8 and IL- 6 with no TNF- $\alpha$ release in human epithelial cells [32]. Studies also showed that PM such as PM2.5 was found to provoke pro-inflammatory cytokines and thus contribute to oxidative stress and inflammation [33]. Animal and human experiments suggest that flavonoids are potent antioxidants that reduce the threat of cardiovascular diseases, cancers, and cerebrovascular diseases [34]. Quercetin is an important flavonoid that has potential effects on health due to its anti-toxic and anti-oxidant function. The alleviate effects of catechin, myricetin, and quercetin were investigated against $\mathrm{N}$-nitrosopiperidine and $\mathrm{N}$-nitrosodibutylamine induced damage in cell 
lines [35]. Studies showed that quercetin was able to defend cells from cellular senescence and oxidative damage in vitro in a dose-dependent manner [36]. Quercetin is a potent free-radical scavenger and chelating agent that chelates the iron metal that is responsible for the production of ROS [37].

Studies showed that flavonoids play a key role in combating toxicity [38]. Dose-dependent studies on quercetin revealed that it inhibited TNF- $\alpha$ formation in lipopolysaccharide induced human volunteers [39]. Other studies showed that, quercetin inhibited oxidative stress in 4 nitro, 3 phenylphenol (PNMPP)-induced rats and hence allowed reversion of GSH-Px, SOD activity, cell viability, and MDA to normal levels [7]. Studies by Chow et al., 2005, revealed that quercetin blocked the formation of DNA ladders, hypodiploid cells and intracellular peroxides induced by $\mathrm{H}_{2} \mathrm{O}_{2}$, through its antioxidant activity [40]. Quercetin was found to significantly decrease LPO, prevent GSH depletion, and DNA damage in HEP G2 cells [41]. Similarly, the oxidative damage induced by biphenyls was prevented by the activity of quercetin [42].

In the present study, quercetin inhibited oxidative stress and inflammation. These data's on the protective ability of quercetin against oxidative stress and inflammation are consistent with previous literatures. Studies explained that quercetin's chemical structure plays a key role in its free-radical scavenging activity. The 0-dihyroxyl group in the C-ring and B-ring is mainly responsible for its activity [43]. The antioxidant activity of quercetin is associated not only with its structure but also with its ability to penetrate and interact with lipid bilayers. Therefore, it can prevent the cytotoxicity of DEPs or PEPs by maintaining normal cell morphology.

\section{CONCLUSION}

The effects of DEP, $P E P, Q, D E P+Q$ and $P E P+Q$ on cytotoxicity, oxidative stress, and inflammation were evaluated in vitro in H9c2 cells. Different concentrations of DEP and PEP induced oxidative stress by increasing MDA and altering anti-oxidant enzyme levels in H9c2 cells. We scrutinized that LDH, NO, TP, MDA, antioxidant, and cytokine levels were ameliorated in DEP/PEP $+\mathrm{Q}$ treated groups. There are no adequate data's on the protective ability of quercetin on DEP/PEP induced toxicity in vitro. Therefore, this study aimed to explore the protective ability of quercetin against DEP/PEP induced in vitro toxicity.

\section{AUTHORS' CONTRIBUTIONS}

Durga M - Manuscript preparation, analysis of results and statistical applications, literature review.

Devasena T - Overall work guidance.

\section{CONFLICTS OF INTEREST}

The authors hereby declare that we have no conflicts of interest.

\section{AUTHORS' FUNDING}

Authors have no funding.

\section{REFERENCES}

1. Rawla P, Sunkara T, Gaduputi V. Epidemiology of pancreatic cancer: Global trends, etiology and risk factors. World J Oncol 2019;10:10-27.

2. Nathiya S, Durga M, Devasena T. Quercetin, encapsulated quercetin and its application-a review. Int J Pharm Pharm Sci 2014;6:20-6.

3. Pandey KB, Ibrahim RS. Current understanding of dietary polyphenols and their role in health and disease. Curr Nutr Food Sci 2009:5:249-63.

4. Ishisaka A, Ichikawa S, Sakakibara H, Piskula MK, Nakamura T, Kato Y, et al. Accumulation of orally administered quercetin in brain tissue and its antioxidative effects in rats. Free Radic Biol Med 2011;51:1329-36.

5. Russo M, Spagnuolo C, Tedesco I, Bilotto S, Russo GL. The flavonoid quercetin in disease prevention and therapy: Facts and fancies. Biochem Pharmacol 2012;83:6-15.

6. Tieppo J, Vercelino R, Dias AS, Vaz MF, Silveira TR, Marroni CA, et al. Evaluation of the protective effects of quercetin in the hepatopulmonary syndrome. Food Chem Toxicol 2007;45:1140-6.

7. Pfeuffer M, Auinger A, Bley U, Kraus-Stojanowic I, Laue C, Winkler P, et al. Effect of quercetin on traits of the metabolic syndrome, endothelial function and inflammation in men with different APOE isoforms. Nutr Metab Cardiovasc Dis 2013;23:403-9.

8. Farombi EO, Onyema OO. Monosodium glutamate-induced oxidative damage and genotoxicity in the rat: Modulatory role of Vitamin C, Vitamin E and quercetin. Hum Exp Toxicol 2006;25:251-9.

9. Mi Y, Zhang C, Li C, Taneda S, Watanabe G, Suzuki AK, Taya K. Quercetin attenuates oxidative damage induced by treatment of embryonic chicken spermatogonial cells with 4-nitro-3-phenylphenol in diesel exhaust particles. Biosci Biotechnol Biochem 2010;74:934-7.

10. Zhang YM. Protective effect of quercetin on aroclor 1254-induced oxidative damage in cultured chicken spermatogonial cells. Toxicol Sci 2005;88:545-50.

11. Durga M, Devasena T, Murthy PB. Toxicity of exhaust nanoparticles. Afr J Pharm Pharmacol 2013;7:318-31.

12. Lehmann AD, Blank F, Baum O, Gehr P, Rothen-Rutishauser BM. Diesel exhaust particles modulate the tight junction protein occludin in lung cells in vitro. Part Fibre Toxicol 2009;26:1-14.

13. Huang CH, Lin LY, Tsai MS, Hsu CY, Chen HW, Wang TD, et al. Acute cardiac dysfunction after short-term diesel exhaust particles exposure. Toxicol Lett 2010;192:349-55.

14. Park S, Nam H, Chung N, Park JD, Lim Y. The role of iron in reactive oxygen species generation from diesel exhaust particles. Toxicol In Vitro 2006;20:851-7.

15. Han JY, Takeshita K, Utsumi H. Noninvasive detection of hydroxyl radical generation in lung by diesel exhaust particles. Free Radic Biol Med 2001;30:516-25.

16. Izawa $\mathrm{H}$, Kohara M, Aizawa $\mathrm{K}$, Suganuma $\mathrm{H}$, Inakuma $\mathrm{T}$, Watanabe $\mathrm{G}$, et al. Alleviative effects of quercetin and onion on male reproductive toxicity induced by diesel exhaust particles. Biosci Biotechnol Biochem 2008;72:1235-41.

17. Bu T, Mi Y, Zeng W, Zhang C. Protective effect of quercetin on cadmium-induced oxidative toxicity on germ cells in male mice. Anat Rec (Hoboken) 2011;294:520-6.

18. Oberdorster G, Yu CP. Lung dosimetry-considerations for noninhalation studies. Exp Lung Res 1999;25:1-6.

19. Parhamifar L, Andersen H, Moghimi SM. Lactate dehydrogenase assay for assessment of polycation cytotoxicity. Methods Mol Biol 2013;948:13-22.

20. Schutz Y. Protein turnover, ureagenesis and gluconeogenesis. Int $\mathbf{J}$ Vitam Nutr Res 2011;81:101-7.

21. Amara N, Bachoual R, Desmard M, Golda S, Guichard C, Lanone S, et al. Diesel exhaust particles induce matrix metalloprotease-1 in human lung epithelial cells via a NADP(H) oxidase/NOX4 redox-dependent mechanism. Am J Physiol Lung Cell Mol Physiol 2007;293:L170-81.

22. Redington AE. Modulation of nitric oxide pathways: Therapeutic potential in asthma and chronic obstructive pulmonary disease. Eur J Pharmacol 2006;533:263-76.

23. Sharma JN, Al-Omran A, Parvathy SS. Role of nitric oxide in inflammatory diseases. Inflammopharmacology 2007;15:252-9.

24. Kono Y, Fridovich I. Superoxide radical inhibits catalase. J Biol Chem 1982;257:5751-4.

25. Sarkar S, Yadav P, Bhatnagar D. Lipid peroxidative damage on cadmium exposure and alterations in antioxidant system in rat erythrocytes: A study with relation to time. Biometals 1998;11:153-7.

26. Galati G, Sabzevari O, Wilson JX, O’Brien PJ. Prooxidant activity and cellular effects of the phenoxyl radicals of dietary flavonoids and other polyphenolics. Toxicology 2002;177:91-104

27. Boveris A, Repetto MG, Bustamante J, Boveris AD, Valdez LB. The concept of oxidative stress in pathology. In: Alvarez S, Evelson P, editors. Free Radical Pathophysiology. Kerala, India: Transworld Research Network; 2008. p. 1-17.

28. Stern A. In: Sies H, editor. Red Cell Oxidative Damage in Oxidative Stress. New York: Academic Press; 1985. p. 331-49.

29. Angulo P. Nonalcoholic fatty liver disease. N Engl J Med 2002;346:1221-31.

30. James O, Day C. Non-alcoholic steatohepatitis: Another disease of affluence. Lancet 1999;353:1634-6.

31. Shaw CA, Robertson S, Miller MR, Duffin R, Tabor CM, Donaldson K, et al. Diesel exhaust particulate-exposed macrophages cause marked endothelial cell activation. Am J Respir Cell Mol Biol 2011;44:840-51.

32. Fujishima H, Satake Y, Okada N, Kawashima S, Matsumoto K, Saito H. Effects of diesel exhaust particles on primary cultured healthy human conjunctival epithelium. Ann Allergy Asthma Immunol 2013;110:39-43.

33. Gioda A, Mattei EF, Velezb BJ. Evaluation of cytokine expression in BEAS cells exposed to fine particulate matter (PM2.5) from specialized 
indoor environments. Int J Environ Health Res 2011;21:106-19.

34. Arta IC, Hollman PC, Feskens EJ, Bueno MH, Kromhout D. Catechin intake might explain the inverse relation between tea consumption and ischemic heart disease: The Zutphen Elderly study. Am J Clin Nutr 2001;74:227-32

35. Delgado ME, Haza AI, Garcia A, Morales P. Myricetin, quercetin, $(+)$-catechin and (-)-epicatechin protect against N-nitrosaminesinduced DNA damage in human hepatoma cells. Toxicol In Vitro 2009;23:1292-7

36. Kook D, Wolf AH, Yu AL. The protective effect of quercetin against oxidative stress in the human RPE in vitro. Invest Ophthalmol Vis Sci 2008:49:1712-20.

37. Kaeko M, Yuki M, Mami I, Tojiro T, Sayuri M, Junji T. Quercetin-4'glucoside is more potent than quercetin-3-glucoside in protection of rat intestinal mucosa homogenates against iron-induced lipid peroxidation. J Agric Food Chem 2004;52:1907-12.

38. Giray B, Gurbay A, Hincal F. Cypermethrin-induced oxidative stress in rat brain and liver is prevented by Vitamin E or allopurinol. Toxicol
Lett 2001;118:139-46

39. Boots AW, Wilms LC, Swennen EL, Kleinjans JC, Bast A, Haenen GR. In vitro and ex vivo anti-inflammatory activity of quercetin in healthy volunteers. Nutrition 2008:24:703-10.

40. Chow JM, Shen SC, Huan SK, Lin HY, Chen YC. Quercetin, but not rutin and quercitrin, prevention of $\mathrm{H}_{2} \mathrm{O}_{2}$-induced apoptosis via antioxidant activity and heme oxygenase 1 gene expression in macrophages. Biochem Pharmacol 2005;69:1839-51

41. Mi Y, Zhang C, Li C, Taneda S, Watanabe G, Suzuki AK, et al. Quercetin protects embryonic chicken spermatogonial cells from oxidative damage intoxicated with 3-methyl-4-nitrophenol in primary culture. Toxicol Lett 2009;190:61-5.

42. Mi Y, Zhang C. Protective effect of quercetin on aroclor 1254-induced oxidative damage in cultured chicken spermatogonial cells. Toxicol Sci 2005;88:545-50.

43. Bors W, Heller W, Michel C, Saran M. Flavonoids as antioxidants: Determination of radical scavenging efficiencies. Methods Enzymol 1990; $186: 343-55$ 